\title{
Renal Adrenomedullin and High Altitude Diuresis
}

\author{
B. HADITSCH ${ }^{1,2}$, A. ROESSLER ${ }^{3}$, H. G. HINGHOFER-SZALKAY ${ }^{1}$ \\ ${ }^{1}$ Institute of Adaptive and Spaceflight Physiology, Graz, ${ }^{2}$ Department of Internal Medicine, Division \\ of Nephrology, and ${ }^{3}$ Institute of Physiology, Center of Physiological Medicine, Medical University, \\ Graz, Austria
}

Received May 23, 2006

Accepted October 25, 2006

On-line available November 6, 2006

\begin{abstract}
Summary
Previous investigations revealed that most of the fluid regulating hormones showed no consistent relationship to the hypoxic diuretic response (HDR). In this study we examined if adrenomedullin (AM), a hypoxia-mediated diuretic/natriuretic peptide is connected to HDR. Thirty-three persons were examined at low altitude (LA), on the third exposure day at $3440 \mathrm{~m}$ (medium altitude, MA) and on the fourteenth day at $5050 \mathrm{~m}$ (high altitude, HA). Nocturnal diuresis rose from $460 \mathrm{ml}$ [interquartile range $302 \mathrm{ml}$ ] at LA to 560 [660] $\mathrm{ml}$ at MA to 1015 [750] $\mathrm{ml}$ at $\mathrm{HA}$ ( $<<0.005$ ). Sodium excretion was similar at LA and MA (41.8 [27.0] vs. 41.4 [28.4] $\mathrm{mM})$ and increased to 80.2 [29.1] $\mathrm{mM}$ at HA $(\mathrm{p}<0.005)$. Urinary AM excretion was 7.9 [3.9] at LA, 7.5 [5.7] pM at MA, and increased to 10.5 [5.1] $\mathrm{pM}(\mathrm{p}<0.05)$ at HA. Urinary AM excretion was correlated to diuresis $(r=0.72, p<0.005)$ and sodium excretion $(r=0.57, p<0.005)$. Plasma AM concentration rose from 16.4 [3.1] to 18.8 [4.9] $\mathrm{pM} / 1$ at $\mathrm{MA}(\mathrm{p}<0.005)$ and to 18.3 [4.3] $\mathrm{pM} / 1$ at $\mathrm{HA}$ $(\mathrm{p}<0.005)$. Plasma AM concentration and urinary AM excretion were not correlated, neither were plasma AM concentration and diuresis or natriuresis. Our data suggest the involvement of increased renal AM production in the pathophysiology of high altitude fluid and sodium loss.
\end{abstract}

\section{Key words}

Adrenomedullin $\bullet$ High altitude $\bullet$ Hypoxic diuretic response $\bullet$ Volume regulation $\bullet$ Adaptation

\section{Introduction}

In a laboratory environment, hypoxic conditions, equivalent to a $25-50 \%$ reduction of inspired oxygen, cause a 'hypoxic diuretic response' (HDR) within 1-2 days of exposure (Honig 1989). HDR occurs with a considerable delay since $13 \mathrm{~h}$ hypoxia under controlled laboratory conditions were shown to be insufficient to produce differences in urine output between simulated altitude $(2800 \mathrm{~m})$ and sea level (Greenleaf et al. 2001). Data on the onset of HDR at the real altitude have not been published yet.
As a result of HDR, total body water is reduced, plasma volume decreases and hemoglobin values rise because renal sodium reabsorption is inhibited, despite low water and sodium intake (Honig 1989). Hypoxia itself appears to be the main stimulus of HDR, as isolated hypoxic perfusion of the carotid body also causes hypoxic diuresis and natriuresis by inhibition of renal tubular sodium reabsorption.

Because HDR persists even after renal denervation, it is likely that some humoral factor is involved in the renal water and sodium excretion, but the role of particular volume-regulating hormones in 
mediating HDR is still contentious. Circulatory levels of atrial natriuretic peptide, antidiuretic hormone, renin, aldosterone and urodilatin seem to be poorly correlated to diuresis or natriuresis (Bärtsch et al. 1991, Swenson et al. 1995, Hildebrandt et al. 2000), whereas endothelin-1 and epinephrine might be involved in the etiology of HDR (Hildebrandt et al. 2000).

Adrenomedullin (AM) is a vasodilating and diuretic/natriuretic peptide that is expressed by a variety of tissues, mainly endothelial and smooth muscle cells. It spills over into the circulation, where its plasma concentration can be quantified (Kitamura et al. 1993, Entzerroth et al. 1995, Samson et al. 1995). Plasma AM levels are elevated with exercise and orthostasis (Tanaka et al. 1995, Rössler et al. 1999). Hypoxia is known to be one of the strongest stimulators for transcription of AM mRNA and for AM release from human endothelial cells (Nakayama et al. 1999, Hofbauer et al. 2000), in part mediated by the so-called hypoxia-inducible factor-1 (HIF-1) (Cormier-Regard et al. 1998).

Two previous studies dealing with the acute hypoxic effect on plasma AM levels produced contradictory results (Toepfer et al. 1998, Hasbak et al. 2002). Plasma AM concentration and urinary AM excretion during long-lasting high altitude (HA) sojourn have not yet been looked into.

The primary goal of this study was to determine if AM is involved in the regulation of HDR during a long-term exposure to hypoxia. Furthermore, we present evidence that the diuretic/natriuretic effect may mainly be mediated by locally produced renal AM rather than by systemic effects of circulating AM.

\section{Methods}

\section{Expedition}

The 'Silver Pyramid 2002' project was an interdisciplinary high altitude research expedition, performed in the Khumbu Himal/Nepal throughout 4 weeks during the spring of 2002. At Kathmandu, the subjects were assigned to either the "trekking team" (TT, 17 subjects, 8 females, aged 19-65 years) or the "climbing team" (CT, 16 subjects, 4 females, aged 23-63 years) and they flew to Lukla $(2800 \mathrm{~m})$ with CT preceding TT by one day. Until medium altitude (MA) was reached, the daily altitude profile and the sleeping altitude were the same in both groups. Thereafter, TT hiked along the Gokyo valley, the highest overnight altitude was $4750 \mathrm{~m}$. The CT group attempted to climb

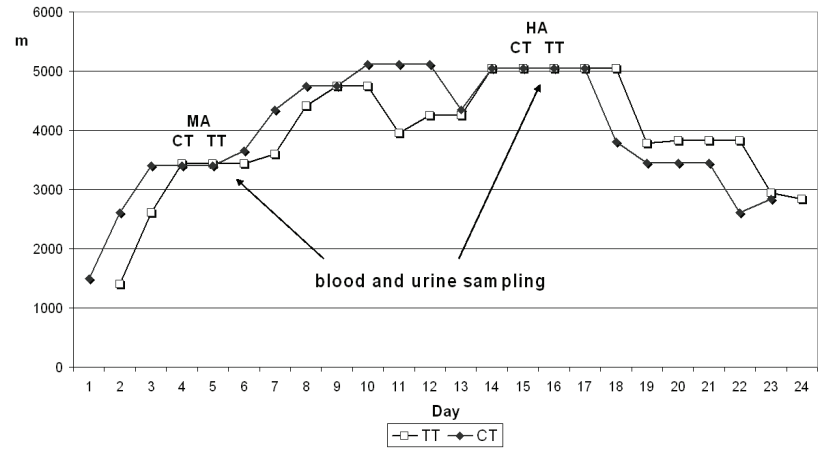

Fig. 1. Overnight altitude profiles of the "climbing team" (CT) and the "trekking team" (TT).

the Imja Tse (also called Island peak, $6189 \mathrm{~m}$ ) before reaching the "Silver Pyramid", the base camp was located at $5150 \mathrm{~m}$ (Fig. 1). There was a daily moderate physical exertion of 6-8 $\mathrm{h}$, the elevation profile was also moderate. The investigation started $36 \mathrm{~h}$ after reaching MA/HA. The previous day was used as a relaxation period, without altitude change or any major physical effort. Both teams enjoyed stable weather conditions.

All group members reached MA. At day 8, five members of TT had to return because of increasing symptoms of acute mountain sickness (AMS), so they were not examined at HA. Thirteen of the CT group tried to climb the summit of Imja Tse, three stayed in the base camp because of mild to moderate AMS symptoms, all sixteen $\mathrm{CT}$ members reached HA.

\section{Experimental procedure}

Our protocol was approved by the University of Graz Ethics Committee. 33 subjects $(21$ males, 12 females, age 19-65 years, height $160-186 \mathrm{~cm}$, body weight 52-91 kg, BMI 20.0-28.7) underwent standard medical, physical and mental examination, were fully informed about possible risks and the experimental procedure, and gave their informed consent.

A baseline examination was performed at low altitude (LA, Herxheim, Germany, 150 m) 6 weeks before starting the climb. Between baseline examination and expedition, none of the subjects had a high altitude sojourn. During the field study in Nepal, each subject underwent two examinations, one during the adaptation on the third day of exposure to MA (Namche Bazar, 3440 $\mathrm{m})$ and another after two weeks acclimatization to HA at the so-called "Silver Pyramid" (Italian-Nepalesian research center Ev-K2-CNR, Lobuche, 5050 m). Subjects were continuously monitored for AMS by expedition doctors, pulse-oxymetry and the individual physical and 
psychological stress was also verified daily.

On days 3 and 14, antecubal venous blood samples were taken in EDTA coated tubes before breakfast between 6:30 and 7:30 h from all subjects in a sitting position after $\mathrm{a} \geq 15 \mathrm{~min}$ resting period. Samples were immediately spun, plasma stored in Trasylol (aprotinin, 500 kallikrein inhibition units per $\mathrm{ml}$ ) prechilled tubes and kept frozen (at $-20{ }^{\circ} \mathrm{C}$ during the expedition, then at $-80{ }^{\circ} \mathrm{C}$ until measurement). At HA, blood samples were also drawn from seven HAaccustomed Sherpas. As stable conditions were anticipated during overnight sleeping periods due to the absence of any physical exertion, no fluid intake and narrow range of ambient temperature, and because the full volume of urine samples could not be stored, urine was collected between 22:00 h. the day before blood sampling and 7:00 h. Urine volumes were determined, an aliquot taken and stored at $-20^{\circ} \mathrm{C}$. Proper functioning of the mobile deep-freezer was permanently controlled by using a minimum-maximum thermometer.

Logistics had to be kept at a minimum level. Throughout the whole trip, food intake was not standardized and fluid intake was allowed ad libitum. Food consisted of usual Sherpa meals with 250-350 mM daily sodium intake, equal to European standards. No food additives were given. Any medication of the subjects was monitored by the expedition doctors, and none of the subjects took any diuretics at MA or HA or the preceding day.

\section{Laboratory procedures}

Plasma and urinary AM concentrations were measured (Ohta et al. 1999) using the radioimmunoassay from Shionogi (Osaka, Japan). AM is sandwiched between biotinylated antibody specific to the intramolecular ring structure and ${ }^{125}$ I-labeled antibody specific to the C-terminal part of human AM. The mixture is reacted with biotin antibody coated beads. The antibody does not cross-react with CGRP, proadrenomedullin N-terminal 20 peptide (PAMP), neuropeptide $\mathrm{Y}$, or amylin. After $20 \mathrm{~h}$ incubation at $4{ }^{\circ} \mathrm{C}$, the beads are washed to remove the unbound antibody, and the remaining radioactivity is gamma counted. AM concentrations are expressed as AM-like immunoreactivity; the minimal detectable concentration for this assay was $0.5 \mathrm{pM} / 1$. The same kit has already been used in determining urinary AM concentrations (Nishikimi et al. 2001), and a prior extraction procedure is not necessary for measurement of urinary AM concentration
(Dötsch et al. 1998).

Urinary and plasma sodium was determined with an electron-sensitive device (AVL 988-4, AVL, Graz, Austria), total plasma proteins and urinary creatinine concentrations were quantified with an automatized analyzer (Cobas Mira, Roche Inc., Switzerland). Urine and plasma osmolalities were measured with a freezing point depression osmometer (Fisk One-Ten, Fiske Associates, Uxbridge, MA). Hematocrit was determined at LA by calculation of red blood cell volume and by microcentrifugation at MA and HA, respectively.

\section{Data analysis}

A two-tailed Wilcoxon matched pairs signed ranks test was used to analyze the differences between the paired measurements for each subject. The null hypothesis was rejected if $p<0.05$. Data analysis was performed using the prism software set (version 4.03, Graphpad Software, Inc). Data are presented as median [interquartile range] unless otherwise stated.

\section{Results}

Fluid and sodium loss, urinary osmolality and urinary creatinine excretion are summarized in Table 1, whereas plasma osmolality, plasma protein and sodium data are shown in Table 2. There was a significant water loss during the ascent, mirrored by hemoconcentration and body weight reduction from 74.2 [13.2] to 69.9 [9.5] $\mathrm{kg}$ (n.s.). Compared to LA, total plasma proteins as a marker of hemoconcentration were increased in both teams during the whole sojourn. Nocturnal diuresis was significantly enhanced in both teams at HA. Overnight urinary osmolality decreased at MA and HA (Table 1). Urinary creatinine excretion decreased as well, but not proportionally to the increase in diuresis. Urinary sodium excretion was unchanged at MA, but increased significantly at HA compared to LA (Table 1). As expected, urinary $\mathrm{Na}^{+}$concentration and urinary osmolality were correlated $(\mathrm{r}=0.88, \mathrm{p}<0.005)$.

Plasma $\mathrm{Na}^{+}$concentration and plasma osmolality were within the normal range in TT and CT (Table 2). Urinary AM excretion showed no obvious changes between LA and MA, but there was a significant increase at HA (Table 3). Plasma AM levels before HA were 16.4 [3.1] pM/1 in both teams (TT 15.9 [3.0], CT 16.7 [3.1]), they increased at MA and remained elevated at HA (Table 3). This pattern was preserved even when hemoconcentration was taken into account. 
Table 1. Nocturnal 9-h diuresis and natriuresis, urinary osmolality and urinary creatinine excretion in the members of CT, in the subjects of TT, who reached HA and who failed (TT-AMS), as well as in all subjects combined.

\begin{tabular}{|c|c|c|c|c|c|}
\hline & & $\begin{array}{l}\text { Diuresis } \\
(\mathrm{ml} / 9 \mathrm{~h})\end{array}$ & $\begin{array}{l}\text { Natriuresis } \\
(\mathrm{mM} / 9 \mathrm{~h})\end{array}$ & $\begin{array}{l}\text { Urinary omolality } \\
((\mathrm{mosm} / \mathbf{k g})\end{array}$ & $\begin{array}{l}\text { Urinary creatinine } \\
\text { excretion }(\mathrm{mg} / 9 \mathrm{~h})\end{array}$ \\
\hline & $L A$ & 460 [302-630] & $41.8[34.1-61.1]$ & 647 [413-840] & 860 [666-1041] \\
\hline Combined & $M A$ & $560[360-1010]^{*}$ & $41.4[30.6-59.0]$ & $236[147-440]^{* *}$ & $630[456-751]^{* *}$ \\
\hline \multirow[t]{2}{*}{$(n=28)$} & $H A$ & $1015[645-1395]^{* *, \# \#}$ & $80.2[65.1-94.2]^{* *, \# \#}$ & $264[183-312]^{* *}$ & $663[524-864]^{* *}$ \\
\hline & $L A$ & 490 [368-655] & $48.7[34.3-76.2]$ & $612[407-840]$ & 921 [709-1073] \\
\hline Climbing Team & $M A$ & 510 [358-823] & $42.4[38.5-59.4]$ & $304[150-453]^{* *}$ & $689[563-867]^{* *}$ \\
\hline \multirow[t]{2}{*}{$(C T, n=16)$} & $H A$ & $810[600-1195]^{* *, \# \#}$ & $80.1[61.4-105.4]^{*, \# \#}$ & $283[223-410]^{* *}$ & $744[567-935]^{*}$ \\
\hline & $L A$ & 405 [273-623] & 38.5 [32.1-49.9] & $647[497-786]$ & 720 [558-942] \\
\hline Trekking Team & $M A$ & $580[418-1055]^{*}$ & $32.7[29.5-54.8]$ & $216[116-289]^{* *}$ & $500[435-638]^{*}$ \\
\hline$(T T, n=12)$ & $H A$ & $1215[895-1443]^{* * \#}$ & $80.2[70.9-89.4]^{* *, \#}$ & $208[143-285]^{* *}$ & $598[506-722]^{*, \#}$ \\
\hline$T T-A M S$ & $L A$ & $290[220-310]$ & $36.2[33.8-48.1]$ & $740[731-878]$ & 612 [581-616] \\
\hline$(n=5)$ & $M A$ & $380[300-480]$ & $25.8[24.6-35.9]$ & $323[197-561]^{*}$ & $528[449-542]^{*}$ \\
\hline
\end{tabular}

Data are presented as median $\left[25^{\text {th }}\right.$ and $75^{\text {th }}$ percentile, respectively]. $* \mathrm{p}<0.05$ and $* * \mathrm{p}<0.005$ compared to LA, ${ }^{*} \mathrm{p}<0.05$ and \#\# $\mathrm{p}<0.005$ HA compared to MA.

Table 2. Total plasma proteins, plasma sodium concentration and plasma osmolality in the members of $\mathrm{CT}$, in the subjects of $\mathrm{TT}$, who reached HA and who failed (TT-AMS), as well as in all subjects combined.

\begin{tabular}{|c|c|c|c|c|}
\hline & & $\begin{array}{l}\text { Total plasma proteins } \\
\text { (g/l) }\end{array}$ & $\begin{array}{c}\text { Plasma } \mathrm{Na}^{+} \text {concentration } \\
(\mathrm{mM} / \mathrm{l})\end{array}$ & $\begin{array}{l}\text { Plasma omolality } \\
\quad(\mathrm{mosm} / \mathrm{kg})\end{array}$ \\
\hline & $L A$ & 66.8 [64.1-70.9] & $145.2[143.6-146.8]$ & 306 [302-310] \\
\hline Combined & $M A$ & $69.4[66.9-71.2]^{*}$ & $146.6[143.7-147.3]$ & 294 [288-304]* \\
\hline \multirow[t]{2}{*}{$(n=28)$} & $H A$ & $71.8[69.1-74.0]^{* *, \#}$ & $145.6[142.6-147.1]$ & 289 [287-292] *,\# \\
\hline & $L A$ & $69.2[66.6-72.2]$ & $144.6[142.8-147.2]$ & 304 [300-305] \\
\hline Climbing Team & $M A$ & $69.7[66.7-71.6]$ & $145.5[141.8-149.4]$ & $293[287-302]^{*}$ \\
\hline \multirow[t]{2}{*}{$(C T, n=16)$} & $H A$ & $72.0[70.3-73.5]$ & $145.4[142.2-148.8]$ & 289 [287-293] *,\# \\
\hline & $L A$ & $64.4[64.0-66.6]$ & $145.5[144.2-146.5]$ & 309 [308-315] \\
\hline Trekking Team & $M A$ & $68.6[67.2-70.7]^{* *}$ & $145.2[144.1-147.1]$ & $293[291-295]^{*}$ \\
\hline$(T T, n=12)$ & $H A$ & $71.0[68.0-74.4]^{* *, \#}$ & $145.4[145.1-146.7]$ & $288[287-290]^{*, \#}$ \\
\hline$T T-A M S$ & $L A$ & $68.6[64.0-69.1]$ & $144.3[143.9-144.5]$ & 304 [299-317] \\
\hline$(n=5)$ & $M A$ & $67.3[64.8-71.6]$ & $145.7[145.4-146.3]$ & $291[288-297]^{*}$ \\
\hline
\end{tabular}

Data are presented as median $\left[25^{\text {th }}\right.$ and $75^{\text {th }}$ percentile, respectively]. $* \mathrm{p}<0.05$ and $* * \mathrm{p}<0.005$ compared to LA, ${ }^{\#} \mathrm{p}<0.05$ and \#\# $\mathrm{p}<0.005$ HA compared to MA.

Urinary AM excretion was significantly related to the amount of diuresis and natriuresis, and negatively correlated to urinary osmolality (Fig. 2). There was no correlation between plasma AM levels and diuresis and/or natriuresis as well as between plasma AM levels and urinary AM excretion (Fig. 3).

Persons reaching $\mathrm{HA}$ did not show any significant difference in either plasma AM levels or 
Table 3. Urinary adrenomedullin excretion and plasma adrenomedullin concentration in the members of CT $(n=16)$, in the subjects of TT, who reached HA and who failed (TT-AMS), and all subjects combined. HA natives (Sherpa) had higher plasma adrenomedullin levels.

\begin{tabular}{|c|c|c|c|}
\hline & & $\begin{array}{l}\text { Urinary AM } \\
\text { excretion } \\
\text { (pM/9h) }\end{array}$ & $\begin{array}{l}\text { Plasma AM } \\
\text { concentration } \\
(\mathrm{pM} / \mathrm{l})\end{array}$ \\
\hline \multirow{3}{*}{$\begin{array}{l}\text { Combined } \\
(n=28)\end{array}$} & $L A$ & 7.9 [6.0-9.9] & $16.4[15.0-18.1]$ \\
\hline & $M A$ & $7.5[4.5-10.2]$ & $18.8[17.1-22.0]^{* *}$ \\
\hline & $H A$ & $10.5[7.5-12.6]^{* *}, \# \#$ & $18.3[17.4-21.7]^{* *}$ \\
\hline Climbing & $L A$ & $9.0[7.5-10.4]$ & 16.7 [14.8-17.9] \\
\hline Team & $M A$ & $7.5[5.2-9.4]^{*}$ & $19.0[17.6-22.0]^{* *}$ \\
\hline$(C T, n=16)$ & $H A$ & $9.5[7.2-14.0]^{\# \#}$ & $19.5[18.0-22.7]^{* *}$ \\
\hline Trekking & $L A$ & $6.9[4.9-7.8]$ & $15.9[15.1-18.1]$ \\
\hline Team & $M A$ & $7.5[3.9-10.6]$ & $18.0[16.5-20.7]^{*}$ \\
\hline$(T T ; n=12)$ & $H A$ & $10.8[9.2-11.4]^{* *, \#}$ & $18.0[16.4-18.8]^{*}$ \\
\hline$T T-A M S$ & $L A$ & $6.1[5.4-6.4]$ & $15.7[15.6-17.4]$ \\
\hline$(n=5)$ & $M A$ & $5.8[4.6-7.1]$ & $23.4[20.3-27.1]^{*}$ \\
\hline Sherpa & $H A$ & & $23.4[22.1-24.2]$ \\
\hline
\end{tabular}

Data are presented as median $\left[25^{\text {th }}\right.$ and $75^{\text {th }}$ percentile, respectively]. * $\mathrm{p}<0.05$ and $* * \mathrm{p}<0.005$ compared to $\mathrm{LA}$, ${ }^{\#} \mathrm{p}<0.05$ and $^{\# \#} \mathrm{p}<0.005$ HA compared to MA.

urinary $\mathrm{AM}$ excretion, diuresis or natriuresis at MA compared to those who developed AMS and consequently had to return to the base camp.

\section{Discussion}

We observed increased urinary adrenomedullin concentrations at high altitude, despite reduced glomerular filtration. Adrenomedullin excretion and high altitude diuresis/natriuresis were correlated, but not to circulating adrenomedullin levels or the duration of high altitude exposure. Increased urinary excretion of AM suggests its renal origin.

Available data on the hormonal control of sodium and water balance at HA are rather contradictory. After several days of exposure to HA, insensible fluid loss, increased sodium excretion and reduced salt-water intake lead to a decrease of total body water by 1-3 liters, with commensurate hemoconcentration (Krzywicki et al. 1971, Jain et al. 1980). Renal sodium and water excretion also rises transiently with acute hypoxemia (Koller et al.
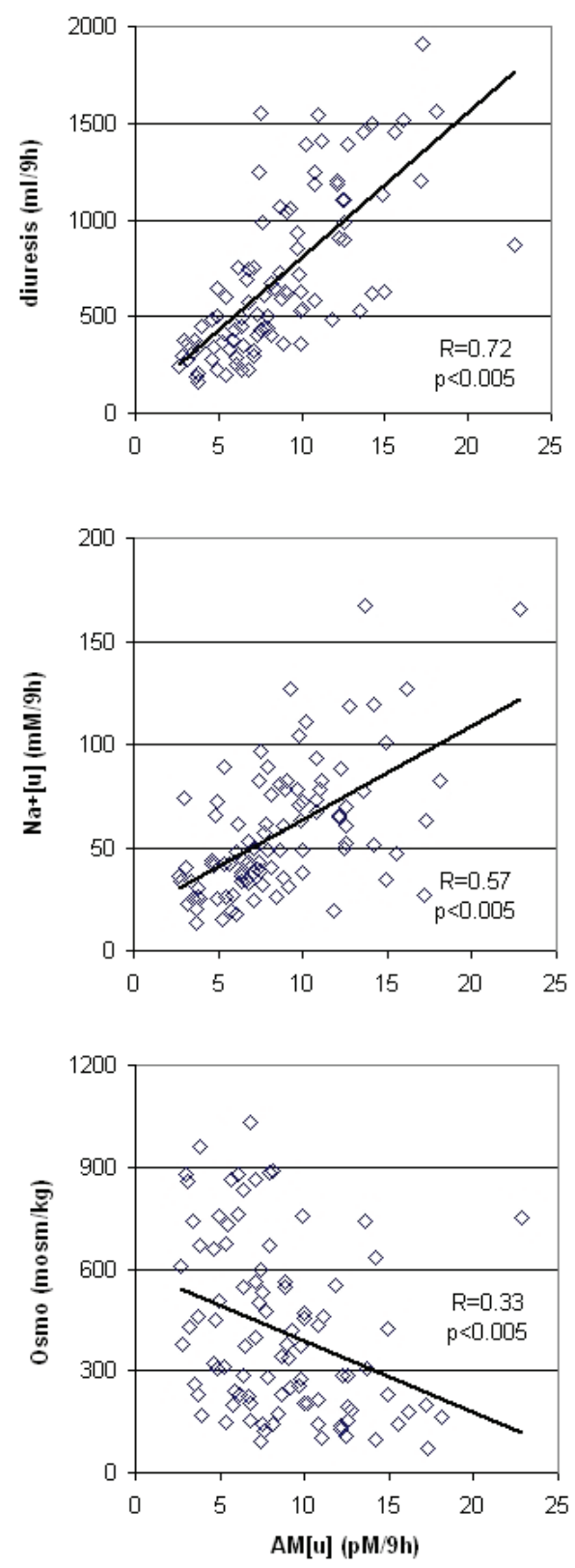

Fig. 2. Nocturnal diuresis, natriuresis $\left(\mathrm{Na}^{+}[\mathrm{u}]\right)$ and urinary osmolality (Osmo) as a function of absolute renal AM excretion $(A M[u])(n=94)$.

1991, Olsen et al. 1992, Hildebrandt et al. 2000). Since this effect persists after renal denervation, an unknown humoral link is likely to exist. In recent field studies as well as under laboratory hypoxic conditions, there was some evidence for an influence of ET-1 and catecholamines on HDR, but no significant correlations between other plasma hormones (vasopressin, aldosterone, urodilatin, ANP) and diuresis/natriuresis were found (Bärtsch et al. 1991, Swenson et al. 1995, Hildebrandt et al. 2000). These results are consistent with earlier studies on the renin-angiotensin-aldosterone 

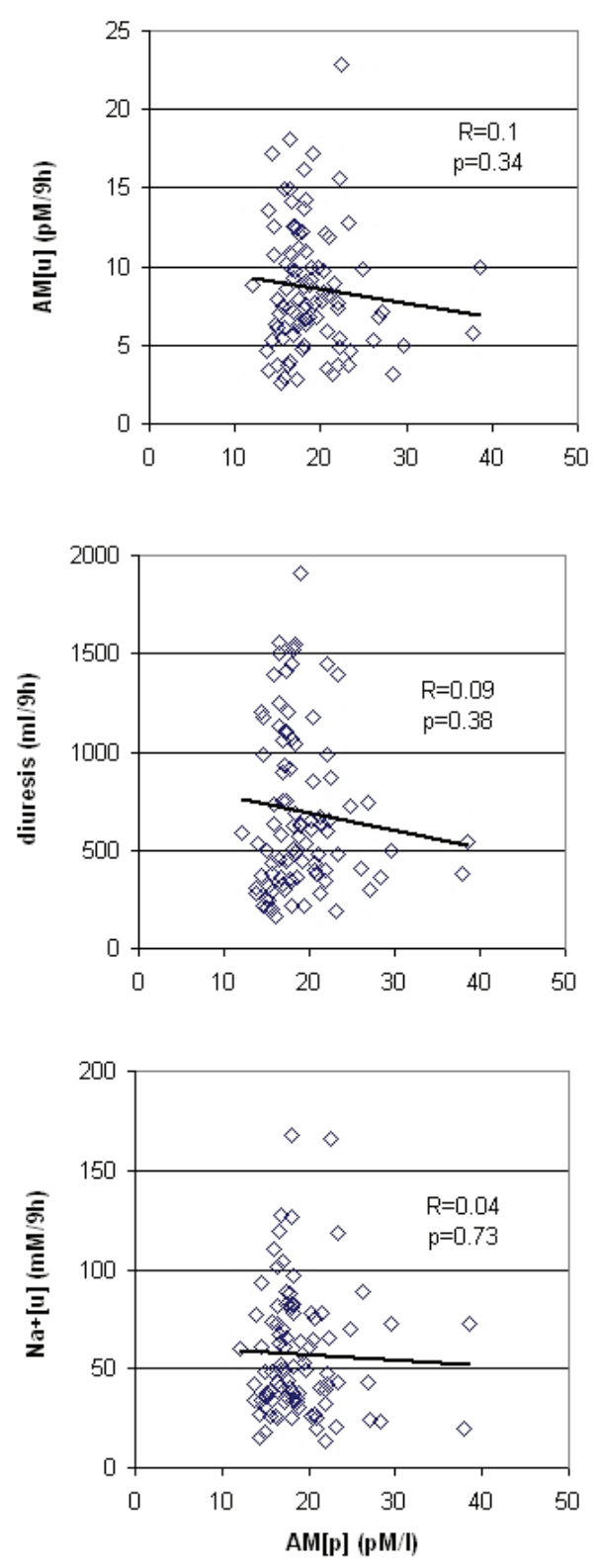

Fig. 3. Urinary $A M$ excretion $(A M[u])$, nocturnal diuresis and natriuresis $\left(\mathrm{Na}^{+}[\mathrm{u}]\right)$ are not correlated to plasma $A M$ levels (AM[p]).

system with HA (Ramirez et al. 1988, Zaccaria et al. 1998). Chronic hypobaric hypoxemia elevates the set point of osmolality-driven vasopressin release. This causes hypovolemia and hyperosmolality, and blunts the natriuretic response to hypertonic volume expansion (Bestle et al. 2002).

It is important to note that the magnitude of hypoxia-related diuresis and natriuresis does not correlate with changes in circulating aldosterone, renin, ANP, and vasopressin (Swenson et al. 1995). This led us to focus on the link between fluid-electrolyte balance at HA and adrenomedullin with its vasodilatory, diuretic and natriuretic effects. Our data suggest, for the first time, a link between HDR and renal AM excretion in vivo.

Hypoxia belongs to the strongest stimuli to release AM from human endothelial cells (Hofbauer et al. 2000). The kidneys are particularly sensitive to hypoxia, and AM production is increased under hypoxic conditions both in renal parenchymal cells as well as in vascular cell cultures (Nagata et al. 1999). This may cause a protective effect against renal hypoxic injury caused by hypoxia-mediated increased ET-1 and decreased NO production. Urinary concentration of AM exceeds its plasma level, suggesting that the kidney is a major site of AM production (Sato et al. 1995). Numerous studies have indicated urinary AM excretion to be mainly driven by renal synthesis (Sato et al. 1995, Jougasaki et al. 1995, Nagata et al. 1999). Receptor autoradiography revealed specific binding sites for AM in renal arteries and glomeruli (Hjelmquist et al. 1997). However, an apparent correlation between plasma and urinary AM has not yet been found. An important local role in the regulation of water balance and sodium excretion seems very likely (Jougasaki et al. 1995, Samson 1999). AM decreases vasopressin and aldosterone (Taylor and Samson 2002), thereby raising renal blood flow, diuresis and natriuresis. Additionally, AM inhibits renal sympathetic nerve activity and increases renin release in a paracrine fashion (Jensen et al. 1997).

Urinary excretion of any substance usually is related to creatinine output. However, as shown earlier and confirmed by our data, creatinine excretion is reduced at HA. Decreased glomerular filtration rate (GFR), probably caused by increased renal sympathetic activity, might explain this effect (Bestle et al. 2002). Consequently, urinary creatinine concentration is not valid as a dilution marker in HDR.

\section{Limitations}

This is an observational study. We report data with partly weak correlations because they represent a first indication that the diuretic and natriuretic effect of AM might be mediated by locally produced renal AM rather than by systemic action of circulating AM. This fits well with the suggestion that AM acts as a paracrine/autocrine rather than an endocrine factor. Additionally, the fact that circulating AM seems to be unrelated to diuresis and natriuresis supports this conclusion. Furthermore, increased sodium excretion together with unchanged plasma sodium levels might be 
explained with an osmotically inactive sodium stored in the tissue compartment (Titze et al. 2002, Gerzer and Heer 2005).

Furthermore, this the first report demonstrating the time course of plasma AM levels during a long-term HA sojourn. The elevation of plasma AM levels in all subjects at MA conceivably mirrors a general acclimatization effect. Interestingly, the increased plasma AM levels of HA sojourners are similar to those seen in high altitude natives.

In conclusion, renal adrenomedullin might be a "missing link" within the fluid regulatory adaptive factors at high altitude, possibly driving the hypoxic diuretic response in concert with the usual volume regulating hormones. The interaction of adrenomedullin with other fluid regulating hormones during long-lasting high altitude exposure will be discussed in a subsequent article.

\section{Acknowledgements}

$<$ Project Silberpyramide 2002 $>$ has been carried out in accordance with the Ev-K2-CNR Committee (Bergamo, Italy) and RONAST (Kathmandu, Nepal). The authors wish to express their gratitude to the Ev-K2-CNR Committee and RONAST for free use of the Pyramid Laboratory-Observatory. We are grateful to the subjects for their cooperation under the demanding conditions and to the kind people of Nepal, without whose help $<$ Project Silberpyramide 2002 $>$ would not have been possible.

We thank Andreas Jantscher for his excellent technical support and Nandu Goswami for his helpful assistance in preparing the manuscript.

This study was supported by the government of Styria and the government of Graz, by a grant of the Friedrich Schmiedl Foundation and a grant of the Lanyar Foundation, by GlaxoSmithKline Austria and by the TravelMedCenter Leonding/Austria.

\section{References}

BÄRTSCH P, PFLÜGER N, AUDETAT M, SHAW S, WEIDMANN P, VOCK P, VETTER W, RENNIE D, OELZ O: Effects of slow ascend to 4559 m on fluid homeostasis. Aviat Space Environ Med 62: 105-110, 1991.

BESTLE MH, OLSEN NV, POULSEN TD, ROACH R, FOGH-ANDERSEN N, BIE P: Prolonged hypobaric hypoxemia attenuates vasopressin secretion and renal response to osmostimulation in men. J Appl Physiol 92: 1911-1922, 2002.

CORMIER-REGARD S, NGUYEN SV, CLAYCOMB WC: Adrenomedullin gene expression is developmentally regulated and induced by hypoxia in rat ventricular cardiac myocytes. J Biol Chem 273: 1787-1796, 1998.

DÖTSCH J, HÄNZE J, KNÜFER V, STEISS JO, DITTRICH K, SEIDEL A, RASCHER W: Increased urinary adrenomedullin excretion in children with urinary-tract infection. Nephrol Dial Transplant 13: 1686-1689, 1998.

ENTZERROTH M, DOODS HN, WIELAND HA, WIENEN W: Adrenomedullin mediates vasodilation via CGRP-1 receptors. Life Sci 56: 259-269, 1995.

GERZER R, HEER M: Regulation of body fluid and salt homeostasis - from observations in space to new concepts on Earth. Curr Pharm Biotechnol 6: 299-304, 2005.

GREENLEAF JE, HINGHOFER-SZALKAY H, RÖSSLER A, FARRELL PA, LOOMIS JL, FEDELE MJ, WEST J, COWELL BS: Plasma sodium-osmotic dissociation and hormonal interaction with drinking-induced hypervolaemia at $2800 \mathrm{~m}$ altitude. Aviat Space Environ Med 72: 522-528, 2001.

HASBAK P, LUNDBY C, OLSEN NV, SCHIFTER S, KANSTRUP IL: Calcitonin gene-related peptide and adrenomedullin release in humans: effects of exercise and hypoxia. Regul Pept 108: 89-95, 2002.

HILDEBRANDT W, OTTENBACHER A, SCHUSTER M, SWENSON ER, BÄRTSCH P: Diuretic effect of hypoxia, hypocapnia, and hyperpnea in humans: relation to hormones and $\mathrm{O}_{2}$ chemosensitivity. $J$ Appl Physiol 88: 599610, 2000.

HJELMQUIST H, KEIL R, MATHAI M, HUBSCHLE T, GERSTBERGER R: Vasodilation and glomerular binding of adrenomedullin in rabbit kidney are not CGRP receptor mediated. Am J Physiol 273: R716-R724, 1997.

HOFBAUER KH, JENSEN BL, KURTZ A, SANDNER P: Tissue hypoxygenation activates the adrenomedullin system in vivo. Am J Physiol 278: R513-R519, 2000.

HONIG A: Peripheral arterial chemoreceptors and the reflex control of sodium and water homeostasis. Am J Physiol 257: R1282-R1302, 1989. 
JAIN SC, BARDHAN J, SWAMY YV, KRISHNA B, NAYAR HS: Body fluid compartements in humans during acute high-altitude exposure. Aviat Space Environ Med 51: 234-236, 1980.

JENSEN BL, KRAMER BK, KURTZ A: Adrenomedullin stimulates renin release and renin mRNA in juxtaglomerular granular cells. Hypertension 29: 1148-1155, 1997.

JOUGASAKI M, WEI CM, AARHUS LL, HEUBLEIN DM, SANDBERG SM, BURNETT JC Jr: Renal localization and action of adrenomedullin: a natriuretic peptide. Am J Physiol 268: F657-F663, 1995.

KITAMURA K, KANGAWA K, KAWAMOTO M, ICHIKI Y, NAKAMURA K, MATSUO H, ETO T: Adrenomedullin: a novel hypotensive peptide isolated from human pheochromocytoma. Biochem Biophys Res Commun 192: 553-560, 1993.

KOLLER EA, BUHRER A, FELDER L, SCHOPEN M, VALLOTTON MB: Altitude diuresis: endocrine and renal responses to acute hypoxia of acclimatized and non-acclimatized subjects. Eur J Appl Physiol 62: 228-234, 1991.

KRZYWICKI HJ, CONSOLAZIO CF, JOHNSON HL, NIELSEN WC Jr, BARNHART RA: Water metabolism in humans during high altitude exposure (4300 m). J Appl Physiol 30: 806-809, 1971.

NAGATA D, HIRATA Y, SUZUKI E, KAKOKI M, HAYAKAWA H, GOTO A, ISHIMITSU T, MINAMINO N, ONO Y, KANGAWA K, MATSUO H, OMATA M: Hypoxia-induced adrenomedullin production in the kidney. Kidney Int 55: 1259-1267, 1999.

NAKAYAMA M, TAKAHASHI K, MURAKAMI O, SHIRATO K, SHIBAHARA S: Induction of adrenomedullin by hypoxia in cultured human coronary artery endothelial cells. Peptides 20: 769-772, 1999.

NISHIKIMI T, HORIO T, KOHMOTO Y, YOSHIHARA F, NAGAYA N, INENAGA T, SAITO M, TERANISHI M, NAKAMURA M, OHRUI M, KAWANO Y, MATSUO H, ISHIMITSU T, TAKISHITA S, MATSUOKA H, KANGAWA K: Molecular forms of plasma and urinary adrenomedullin in normal, essential hypertension and chronic renal failure. J Hypertens 19: 765-773, 2001.

OHTA H, TSUJI T, ASAI S, SASAKURA K, TERAOKA H, KITAMURA K, KANGAWA K: One-step direct assay for mature-type adrenomedullin with monoclonal antibodies. Clin Chem 45: 244-251, 1999.

OLSEN NV, KANSTRUP IL, RICHALET JP, HANSEN JM, PLAZEN G, GALEN FX: Effects of acute hypoxia on renal and endocrine function at rest and during graded exercise in hydrated subjects. J Appl Physiol 73: 20362043, 1992.

RAMIREZ G, BITTLE PA, HAMMOND M, AYERS CW, DIETZ J, COLICE GL: Regulation of aldosterone secretion during hypoxemia at sea level and moderately high altitude. J Clin Endocrinol Metab 67: 1162-1165, 1988.

RÖSSLER A, LÁSZLÓ Z, HADITSCH B, HINGHOFER-SZALKAY HG: Effect of postural changes on adrenomedullin plasma levels in humans. Hypertension 34: 1147-1151, 1999.

SAMSON WK: Adrenomedullin and the control of fluid and electrolyte homeostasis. Annu Rev Physiol 61: 363-389, 1999.

SAMSON W, MURPHY T, SCHELL D: A novel vasoactive peptide, adrenomedullin, inhibits pituitary adrenocorticotropin release. Endocrinology 136: 2349-2352, 1995.

SATO K, HIRATA Y, IMAI T, IWASHINA M, MARUMO F: Characterization of immunoreactive adrenomedullin in human plasma and urine. Life Sci 57: 189-194, 1995.

SWENSON ER, DUNCAN TB, GOLDBERG SV, RAMIREZ G, AHMAD S, SCHOENE RB: Diuretic effect of acute hypoxia in humans: relationship to hypoxic ventilatory responsiveness and renal hormones. $J$ Appl Physiol 78: 377-383, 1995.

TANAKA M, KITAMURA K, ISHIZAKA Y, ISHIYAMA Y, KATO J, KANGAWA K, ETO T: Plasma adrenomedullin in various diseases and exercise-induced change in healthy subjects. Intern Med 34: 728-733, 1995.

TAYLOR MM, SAMSON WK: Adrenomedullin and the integrative physiology of fluid and electrolyte balance. Microsc Res Tech 57: 105-109, 2002.

TITZE J, MAILLET A, LANG R, GUNGA HC, JOHANNES B, GAUQUELIN-KOCH G, KIHM E, LARINA I, GHARIB C, KIRSCH KA: Long-term sodium balance in humans in a terrestrial space station simulation study. Am J Kidney Dis 40: 508-516, 2002. 
TOEPFER M, HARTMANN G, SCHLOSSHAUER M, HARTMANN H, TSCHÖP M, FISCHER R, HUBER RM: Adrenomedullin: a player at high altitude? Chest 113: 1428, 1998.

ZACCARIA M, ROCCO S, NOVENTA D, VARNIER M, OPOCHER G: Sodium regulating hormones at high altitude: basal and post-exercise levels. J Clin Endocrinol Metab 83: 570-574, 1998.

\section{Corresponding author}

B. Haditsch, Department of Internal Medicine, Division of Nephrology, Medical University of Graz, Auenbruggerplatz 27, 8036 Graz, Austria. Fax:+43/316/385-3548. E-mail: bernd.haditsch@meduni-graz.at 